\title{
Bacterially induced calcium carbonate precipitation and strontium coprecipitation in a porous media flow system
}

\section{Authors: Ellen G. Lauchnor, Logan N. Schultz, Steven Bugni, Andrew C. Mitchell, Alfred B. Cunningham, and Robin Gerlach}

NOTICE: This document is the unedited author's version of a Submitted Work that was subsequently accepted for publication in Environmental Science \& Technology, copyright (C) American Chemical Society after peer review. To access the final edited and published work, see http://dx.doi.org/10.1021/es304240y.

Lauchnor EG, Schultz LN, Bugni S, Mitchell AC, Cunningham AB, Gerlach R , "Bacterially induced calcium carbonate precipitation and strontium coprecipitation in a porous media flow system," Environ Sci Technol. 2013 47(3):1557-1564. 


\section{Bacterially Induced Calcium Carbonate Precipitation and Strontium Coprecipitation in a Porous Media Flow System}

Ellen G. Laychnor, ${ }^{\dagger}, \#$ Logan N. Schultz, ${ }^{\dagger}+,, \perp, \#$ Steven Bugni, ${ }^{\dagger, \S}$ Andrew C. Mitchell,

Alfred B. Cunningham, $\uparrow, \S$ and Robin Gerlach*, $\dagger, \dagger$

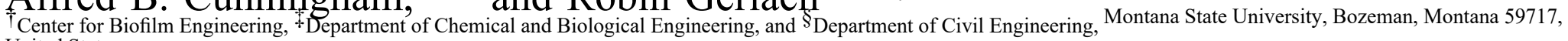
United States

$\stackrel{\perp}{\perp}$ Nano-Science Center, Department of Chemistry, University of Copenhagen, Denmark

// Institute of Geography and Earth Sciences, Aberystwyth University, SY23 3DB, U.K.

ABSTRACT: Strontium-90 is a principal radionuclide contam-inant in the subsurface at several Department of Energy sites in the Western U.S., causing a threat to groundwater quality in areas such as Hanford, WA. In this work, we used laboratory-scale porous media flow cells to examine a potential remediation strategy employing coprecipitation of strontium in carbonate minerals. $\mathrm{CaCO}_{3}$ precipitation and strontium coprecipitation were induced via ureolysis by Sporosarcina pasteurii in two-dimensional porous media reactors. An injection strategy using pulsed injection of calcium mineralization medium was tested against a continuous injection strategy. The pulsed injection strategy involved periods of lowered calcite saturation index combined with short high fluid velocity flow periods of calcium mineralization medium followed by stagnation (no-ï $\neg$,ow) periods to promote homogeneous $\mathrm{CaCO} 3$ precipitation.

By alternating the addition of mineralization and growth media the pulsed strategy promoted $\mathrm{CaCO}_{3}$ precipitation while sustaining the ureolytic culture over time. Both injection strategies achieved ureolysis with subsequent $\mathrm{CaCO}_{3}$ precipitation and strontium coprecipitation. The pulsed injection strategy precipitated $71-85 \%$ of calcium and $59 \%$ of strontium, while the continuous injection was less efficient and precipitated $61 \%$ of calcium and $56 \%$ of strontium. Over the 60 day operation of the pulsed reactors, ureolysis was continually observed, suggesting that the balance between growth and precipitation phases allowed for continued cell viability. Our results support the pulsed injection strategy as a viable option for ureolysis-induced strontium coprecipitation because it may reduce the likelihood of injection well accumulation caused by localized mineral plugging while $\mathrm{Sr}$ coprecipitation efficiency is maintained in field-scale applications.



INTRODUCTION

Microbially induced calcium carbonate precipitation (MICP) has been studied extensively in recent years and has implications in many environmental applications, including but not limited to aquifer decontamination, ${ }^{1}$ soil stabilization, ${ }^{2}$ and carbon capture and storage $(\mathrm{CCS}){ }^{3}$ The high stability of carbonates and the potential for coprecipitation of heavy metals and radionuclides such as strontium-90 within calcium carbonate $\left(\mathrm{CaCO}_{3}\right)$ are attractive attributes for engineering applications.

The hydrolysis of urea $\left(\mathrm{NH}_{2} \mathrm{CONH}_{2}\right)$ (i.e., ureolysis) by native or introduced microorganisms is one of several microbial pathways that can be used to induce in situ $\mathrm{CaCO}_{3}$ precipitation. ${ }^{4,5}$ Ureolysis produces ammonia $\left(\mathrm{NH}_{3}\right)$ and dissolved inorganic carbon (DIC) (eq 1), which increases alkalinity (eqs 2 and 3), ultimately favoring the precipitation of $\mathrm{CaCO}_{3}$ in the presence of dissolved calcium (eq 4). ${ }^{6}$

$$
\begin{aligned}
& 2 \mathrm{NH}_{3}+2 \mathrm{H}_{2} \mathrm{O} \leftrightarrow 2 \mathrm{NH}_{4}^{+}+2 \mathrm{OH}^{-} \\
& \mathrm{CO}_{2}+2 \mathrm{OH}^{-} \leftrightarrow \quad \mathrm{HCO}_{3}+{ }_{\mathrm{O}}^{-} \overleftrightarrow{\mathrm{H}} \mathrm{CO}_{3}{ }^{2-}+\mathrm{H}_{2} \mathrm{O} \\
& \mathrm{Ca}^{2+}+\mathrm{CO}_{3}{ }^{2-} \leftrightarrow \mathrm{CaCO}_{3}(\mathrm{~s})
\end{aligned}
$$

The precipitation of $\mathrm{CaCO}_{3}$ is governed by the following parameters: calcium concentration, $\mathrm{DIC}, \mathrm{pH}$, and the presence of nucleation sites. ${ }^{7}$ Bacterial cells have been shown to function as nucleation sites, and studies have confirmed the precipitation of $\mathrm{CaCO}_{3}$ on bacterial cell surfaces. ${ }^{5,8}$ Previous research has demonstrated that the soil bacterium and model organism Sporosarcina pasteurii can efficiently perform ureolysis, resulting in $\mathrm{CaCO}_{3}$ precipitation, predominantly as the polymorph

$$
\mathrm{NH}_{2} \mathrm{CONH}_{2}+2 \mathrm{H}_{2} \mathrm{O} \rightarrow 2 \mathrm{NH}_{3}+\mathrm{CO}_{2}
$$


calcite. $^{4,6,9-12}$ S. pasteurii is a moderate alkaliphile with a $\mathrm{pH}$ optimum for growth of 9.2 and a constitutively expressed urease enzyme, making it well-suited for ureolytic biomineralization. $^{13}$

Strontium-90 $\left({ }^{90} \mathrm{Sr}\right)$ is a uranium fission byproduct that is a groundwater contaminant present at several Department of Energy sites in the Western U.S. ${ }^{14,15}$ The mobility and known carcinogenic effects of ${ }^{90} \mathrm{Sr}$ pose a risk to groundwater usability. ${ }^{9,16}$ However, $\mathrm{Sr}$ is readily coprecipitated with $\mathrm{CaCO}_{3}$ and ion exchanged by substituting for $\mathrm{Ca}$ in lattice sites of calcite. ${ }^{17,18}$ While $\mathrm{Sr}$ may slightly inhibit crystal growth, ${ }^{19}$ previous studies have demonstrated the effective immobilization of Sr using ureolytic MICP..$^{20-22}$ Due to the stability of calcite and the short half-life of ${ }^{90} \mathrm{Sr}$ (29 years), it should be possible to sequester ${ }^{90} \mathrm{Sr}$ for sufficient time to allow radioactive decay. Therefore, ${ }^{90} \mathrm{Sr}$ is a candidate for in situ coprecipitation in calcite via MICP. ${ }^{21-23}$

Field studies have demonstrated successful stimulation of ureolytic activity in a native groundwater microbial community for application of MICP in the subsurface but have encountered plugging near the injection well, leading to restricted urea transport. ${ }^{9,24}$ This indicates the need to understand and control the rate and extent of precipitation in flowing systems. Previous work has also shown potential loss of ureolytic activity due to $\mathrm{CaCO}_{3}$ precipitation on cell surfaces. ${ }^{22,25,26}$ Thus, strategies for sustained remediation using ureolytic MICP must consider maintenance of bacterial activity as well as spatial control of precipitation. Ultimately, the effectiveness of this technology will be dictated by phenomena that occur at the micrometer scale or smaller and will be influenced by controllable field scale parameters such as concentrations, flow rates and amendment injection strategies.

This study examines ureolysis-induced $\mathrm{CaCO}_{3}$ precipitation by $S$. pasteurii under constant flow and pulsed flow conditions in porous media reactors, where the ureolytic bacteria predominantly exist as attached microbial communities (e.g., biofilms). The primary objectives were (1) to understand the distribution of mineral precipitates along the flow path to provide insight into transport optimization and (2) to assess the coprecipitation of $\mathrm{Sr}$ in a porous media flow system by comparing pulsed flow and continuous flow injection schemes in single- and dual-injection port systems. These objectives were achieved using two-dimensional reactor systems that provided an ideal porous medium environment and allowed for visual evaluation of precipitate formation. Combined with aqueous chemistry and mineral phase analyses, this study contributes toward improved field-scale immobilization strategies.

\section{EXPERIMENTAL METHODS}

Reactor System. The quasi-2D porous media reactors were constructed from polycarbonate plates [Supporting Information (SI), Figure S1]. The reactor includes two inlets with mixing zones to minimize entrance effects. The bottom polycarbonate plates of the reactors contain an $8.5 \mathrm{~cm} \times 3.8$ $\mathrm{cm}$ zone etched with $1 \mathrm{~mm} \times 1 \mathrm{~mm}$ diagonal channels, creating a homogeneous pattern of $1 \mathrm{~mm}^{3}$ square pegs, which serve as porous media elements. A glass coverslip provides the top surface of the reactors $1 \mathrm{~mm}$ above the bottom of the etched plate. Immediately preceding the reactor is an injection/ inoculation port and flow break designed to prevent upstream contamination and precipitation. Immediately following the outlet is a sample port to allow effluent sampling. Silicone tubing (Masterflex size 16) connected the media source to the reactors via a peristaltic pump upstream of the reactors (Masterflex model 7521-50). The single inlet system described in Schultz et al. ${ }^{27}$ was also used to compare a single injection point to the dual injection reactors.

Growth and Mineralization Medium. The calcium mineralization medium (CMM), modified from Ferris et al., ${ }^{1}$ contained nutrient broth (Becton, Dickinson and Co., $3 \mathrm{~g} \mathrm{~L}^{-1}$ ), urea (Fisher Scientific, $20 \mathrm{~g} \mathrm{~L}^{-1}$ ), $\mathrm{NH}_{4} \mathrm{Cl}$ (Fisher Scientific, $10 \mathrm{~g}$ $\mathrm{L}^{-1}$ ), and $\mathrm{CaCl}_{2} \cdot 2 \mathrm{H}_{2} \mathrm{O}$ (Acros, $3.7 \mathrm{~g} \mathrm{~L}^{-1}$ ). The $\mathrm{pH}$ was adjusted to 6.0 prior to adding $\mathrm{CaCl}_{2} \cdot 2 \mathrm{H}_{2} \mathrm{O}$ and filter sterilizing. For the Sr-inclusive media, $\mathrm{SrCl}_{2} \cdot 6 \mathrm{H}_{2} \mathrm{O}$ was added before filtration to yield a final $\mathrm{Sr}$ concentration of either 21 or $210 \mathrm{mg} \mathrm{L}^{-1}$ for low- and high-Sr media, respectively. CMM without $\mathrm{CaCl}_{2} \cdot 2 \mathrm{H}_{2} \mathrm{O}$ or $\mathrm{SrCl}_{2} \cdot 6 \mathrm{H}_{2} \mathrm{O}$ (CMM-) was also prepared for growth of the ureolytic biofilm in the absence of $\mathrm{CaCO}_{3}$ precipitation, according to the same protocol.

Culturing and Inoculation. A frozen stock culture of $S$. pasteurii (ATCC 11859) was used to inoculate $100 \mathrm{~mL}$ of brain heart infusion (BHI) (Oxoid Ltd., Cambridge, UK) amended with urea $\left(20 \mathrm{~g} \mathrm{~L}^{-1}\right)$ and incubated at $30^{\circ} \mathrm{C}$ and $150 \mathrm{rpm}$ for $24 \mathrm{~h}$. A $0.1 \mathrm{~mL}$ aliquot was transferred into fresh medium (50 $\mathrm{mL}$ ) and grown for another $18 \mathrm{~h}$. The culture was centrifuged at $4{ }^{\circ} \mathrm{C}$ and $4455 \mathrm{~g}$ for $30 \mathrm{~min}$ (Sorvall Instruments, RC5C), and the cells were resuspended in ( $\mathrm{Ca}$ - and $\mathrm{Sr}$-free) CMM-. The process was repeated once more before $4 \mathrm{~mL}$ (or approximately two reactor pore volumes) of the culture $\left(\mathrm{OD}_{600}\right.$ $=0.4,100 \mu \mathrm{L}$ in 96-well plate) was injected into the flow system via both injection ports, and the bacteria were allowed to attach for $1.5 \mathrm{~h}$ before medium flow was started.

Fluid Injection Strategies. Continuous Flow (CF). To evaluate MICP under continuous addition of $\mathrm{Ca}$ and $\mathrm{Sr}$, two dual injection port reactors were fed with $0.18 \mathrm{~mL} \mathrm{~min}^{-1}$ of sterile CMM, resulting in a hydraulic residence time of 15.3 $\mathrm{min}$ in the porous media region and $30 \mathrm{~min}$ in the reactor including inlet and outlet zones. The reactors were inoculated using the methods described in the previous section. One reactor was operated in the absence of $\mathrm{Sr}$ and the other with 21 $\mathrm{mg} \mathrm{L}{ }^{-1} \mathrm{Sr}$ for $5 \mathrm{~h}$ of the experiment and then increased to 210 $\mathrm{mg} \mathrm{L}^{-1} \mathrm{Sr}$ to assess coprecipitation at high $\mathrm{Sr}$ concentration. The reactors were terminated after $11 \mathrm{~h}$, during which $118 \mathrm{mg}$ of $\mathrm{Ca}$ were injected.

Pulsed Flow (PF). The second injection strategy used pulsed injections with intermittent batch periods and alternating injection of CMM with (Ca- and Sr-free) CMM- for regrowth of attached cells (biofilm) inactivated by $\mathrm{CaCO}_{3}$ encrustation. Two reactors were operated in the presence and absence of $\mathrm{Sr}$, the former being operated for the first 15 pulses of the experiment with $21 \mathrm{mg} \mathrm{L}^{-1} \mathrm{Sr}$ and then increasing to $210 \mathrm{mg}$ $\mathrm{L}^{-1} \mathrm{Sr}$. After inoculating S. pasteurii and allowing a $1.5 \mathrm{~h}$ bacterial attachment period, the reactors were operated under continuous flow of sterile CMM- $\left(0.5 \mathrm{~mL} \mathrm{~min}{ }^{-1}\right)$ for $12 \mathrm{~h}$ to promote growth of attached microbes. Subsequently, pulsed injection using sterile solutions was initiated according to the following steps: (1) nutrient broth with $10 \mathrm{~g} \mathrm{~L}^{-1} \mathrm{NH}_{4} \mathrm{Cl}$ at $\mathrm{pH}$ 6.0 was pumped through the reactors $\left(0.5 \mathrm{~mL} \mathrm{~min}^{-1}\right)$ for 30 min to lower the system $\mathrm{pH}$ and saturation state of $\mathrm{CaCO}_{3}$. (2) Two pore volumes of CMM were pumped at a flow rate of 0.5 $\mathrm{mL} \mathrm{min}^{-1}$ and a $24 \mathrm{~h}$ no-flow period followed. The higher flow rate was used to minimize precipitation during flow, and intermittent no-flow periods were intended to facilitate uniform precipitation throughout the reactors. (3) After a $24 \mathrm{~h}$ no-flow period, two pore volumes of sterile Ca- and Sr-free CMM- were 

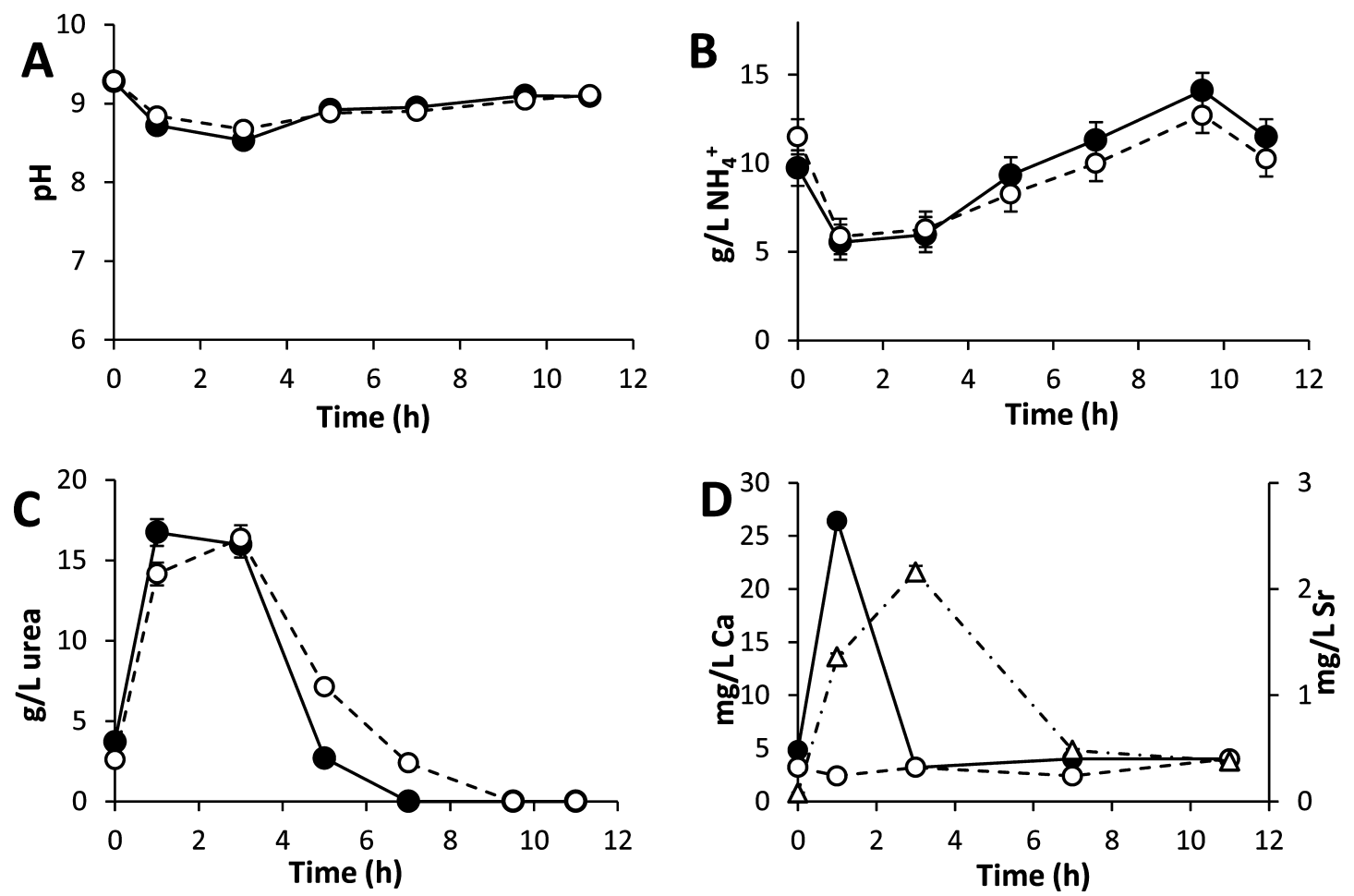

Figure 1. Effluent liquid analyses from continuous flow reactors fed with $1 \mathrm{~g} / \mathrm{L} \mathrm{Ca}$. Sr-free (O) and Sr-inclusive reactor (O). (A) Effluent pH, (B) total $\mathrm{NH}_{4}^{+}$, (C) urea, and (D) $\mathrm{Ca} / \mathrm{Sr}$ in liquid samples taken over time during operation of reactors. (D) Dissolved $\mathrm{Sr}(\triangle)$ in the Sr-inclusive reactor; no $\mathrm{Sr}$ was detected in liquid samples from the $\mathrm{Sr}$-free reactor. Influent $\mathrm{pH}$ and total $\mathrm{NH}_{4}^{+}$were 6.0 and $3 \mathrm{~g} \mathrm{~L}^{-1}$, respectively. Influent urea and calcium concentrations were 20 and $1 \mathrm{~g} \mathrm{~L}^{-1}$, respectively. Error bars for parts $\mathrm{B}, \mathrm{C}$, and $\mathrm{D}$ are standard deviations of analytical measurements and are smaller than data points in some cases. Influent $\mathrm{Sr}$ was increased from 21 to $210 \mathrm{mg} \mathrm{L}^{-1}$ at $5 \mathrm{~h}$.

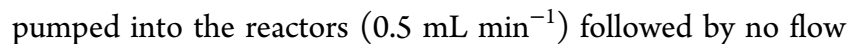
for $24 \mathrm{~h}$ to promote bacterial growth without precipitation. (4) The pulsing procedure in steps 2 and 3 was repeated for 30 pulses of CMM, equivalent to the 30 pore volumes of CMM pumped through during the continuous flow experiments.

Analytical Methods. Effluent Chemistry. Liquid samples $(1 \mathrm{~mL})$ were collected from effluent ports of both continuous flow (CF) and pulsed flow (PF) reactors, passed through a 0.2 $\mu \mathrm{m}$ syringe filter (Corning Inc.), and analyzed for $\mathrm{pH}$ and dissolved concentrations of $\mathrm{NH}_{4}{ }^{+}, \mathrm{Ca}, \mathrm{Sr}$, and urea. $\mathrm{NH}_{4}{ }^{+}$was determined by a modified Nessler method (see SI). Concentrations of dissolved (i.e., filtered) $\mathrm{Ca}$ and $\mathrm{Sr}$ were measured via ion chromatography (see SI). Urea was measured using a derivatization reaction and subsequent HPLC with a C18 $150 \mathrm{~mm} \times 4.6 \mathrm{~mm}$ column (Agilent). The methods for derivatization and HPLC detection of urea are described in detail elsewhere. ${ }^{28}$ To verify the presence of viable bacteria, effluent samples (unfiltered) were serially diluted and dropplated on BHI agar with $2 \%$ urea, and colony forming units (CFUs) were counted. ${ }^{29}$

Microscopy and Mineral Analysis. At the end of experiments, stereo microscope (Nikon SMZ1500, 7.5×-40×) images were taken along the length of the reactors to evaluate size and density of precipitates. The image analysis software MetaMorph v.7.4.6 (Universal Imaging Corp.) was used to measure the precipitates using an intensity threshold and the Integrated Morphometry Analysis application. In the pulsed reactors, the crystals were too dense to threshold and had to be manually measured using the caliper tool in Metamorph. At least 20 crystals were measured for each data point.
Scanning electron microscopy (SEM) and X-ray powder diffraction (XRD) were performed on the glass coverslips from the reactors to evaluate the crystal morphology, mineralogy, and the association of precipitates with bacteria. Details can be found in the SI.

Acid Digestion of Precipitates. The distributions of immobilized $\mathrm{Ca}$ and $\mathrm{Sr}$ were assessed at the end of the experiments by digestion of the calcium carbonate with $10 \%$ nitric acid $\left(\mathrm{HNO}_{3}\right)$. Reactors were gently rinsed with DI water and air-dried upon removal of the coverslips. Precipitates were digested in $1.6 \mathrm{~cm}$ sections along the flow path in $10 \mathrm{~mL}$ of $10 \% \mathrm{HNO}_{3}$ by rinsing the reactor and glass coverslip surfaces with a serological pipet. Rinsing was performed over a large beaker so that the liquid runoff was collected. Ten milliliters of acid was recovered from each rinsing step, verifying that the entire digested sample was recovered. Digested samples were added to $10 \mathrm{~mL}$ of deionized $\mathrm{H}_{2} \mathrm{O}$, analyzed using an Agilent 7500 ICP-MS after further dilution in 5\% nitric acid and compared to certified standards (Agilent Technologies, Environmental Calibration Standard 5183-4688).

\section{RESULTS AND DISCUSSION}

Effluent Aqueous Chemistry. Continuous Flow System. In an initial experiment, sterile CMM was pumped through the reactors without bacterial inoculation and no significant changes in chemistry or abiotic mineral formation were observed. After inoculation, increases in $\mathrm{NH}_{4}^{+}$concentration and $\mathrm{pH}$ in the reactor effluents indicated that ureolysis occurred in both $\mathrm{Sr}$-free and Sr-inclusive reactors (Figure 1A,B), and CFUs in effluent samples indicated a viable microbial culture (data not shown). The same experiment using S. pasteurii was 
performed with single injection port reactors and was reported by us previously, with similar effluent results as Figure $1 .^{27}$ However, in the single injection port experiment, plugging around the inlet port occurred in the Sr-free system after $14 \mathrm{~h}$ and in the Sr-inclusive system after $15 \mathrm{~h},{ }^{27}$ which might be related to the reduced cross-sectional area around the inlet port of the single inlet reactors compared to the spatially distributed injection in the dual inlet reactor.

At all sample times, both reactor effluents contained much lower $\mathrm{Ca}$ and $\mathrm{Sr}$ concentrations than the influent CMM (Figure $1 \mathrm{C}, \mathrm{D})$, and precipitate volume in the reactors was observed to increase over time. At the final sample time $(11 \mathrm{~h})$, the effluent of both reactors contained $<1 \%$ of the influent $\mathrm{Ca}$ concentration, and the $\mathrm{Sr}$-inclusive reactor effluent contained $<1 \%$ of the influent $\mathrm{Sr}$ concentration (Figure 1D). A total of $118 \mathrm{mg}$ of Ca was injected into each reactor during continuous flow. On the basis of effluent concentration measurements, less than $1 \mathrm{mg}$ of the $118 \mathrm{mg}$ of $\mathrm{Ca}$ injected remained in the effluent, which was less than $1 \%$ of the influent $\mathrm{Ca}$ concentration.

Pulsed Flow System. Thirty CMM pulses were performed on the pulsed flow (PF) reactors with the assumption that precipitation would occur only during the no-flow periods after each injection, due to higher injection rates than in the $\mathrm{CF}$ experiment. Increases in $\mathrm{NH}_{4}^{+}$and $\mathrm{pH}$ (Figure 2A,B), along with no detection of urea above $10 \mathrm{mg} \mathrm{L}^{-1}$ in the effluent indicated that near complete ureolysis occurred during no-flow periods.

On the basis of plate counts, viable detached cells were present in the PF reactor effluents for the entire 60 day experiment (data not shown). Combined with the observations of ureolysis, this verifies that ureolytic bacteria were maintained in the reactors over the duration of the experiment. The resuscitation pulse (i.e., CMM-) after each CMM pulse was likely a key factor in maintaining the viable culture and ureolytic activity in the reactors. Previous researchers have observed cell encapsulation and inactivation within $\mathrm{CaCO}_{3}$ during mineralization. 4,10,26,30 The pulsed flow strategy demonstrated here provides a method for maintaining viable microbial populations and increasing the potential application of this technology for sustained, long-term use.

Dissolved Ca concentrations after the CMM no-flow phase were at or below the detection limit of $5 \mathrm{mg} \mathrm{L}^{-1}$ (data not shown), which is less than $1 \%$ of the influent $\mathrm{Ca}$. According to an aqueous chemistry simulation in Visual MINTEQ v. 3.0, with complete ureolysis in the CMM, $99.8 \%$ of $\mathrm{Ca}$ is predicted to precipitate with the generated carbonate, assuming that $\mathrm{CaCO}_{3}$ is present as calcite. MINTEQ calculations also indicate that the saturation index of $\mathrm{CaCO}_{3}$ increases from -13 in the sterile $\mathrm{CMM}$ at $\mathrm{pH} 6$ to a saturation index of 3.5 if complete ureolysis occurs. Effluent $\mathrm{Sr}$ concentrations measured after CMM batch periods in the PF reactors were $0.4-0.8 \mathrm{mg} \mathrm{L}^{-1}$ (Figure 2C).

Calcium Carbonate Precipitation. Microscopic Analysis. SEM images of the CF reactors revealed both well-defined crystal faces (Figure 3A) and spherical precipitates (Figure 3B) in association with cells. XRD analysis of crystals from single inlet reactors operated under CF conditions showed strong similarities with calcite (SI, Figure S2). SEM of the PF reactors revealed predominantly well-defined crystal faces, and XRD spectra suggest that these precipitates are calcite, while no clear evidence of vaterite or aragonite was obtained (SI, Figure S3). In both $\mathrm{CF}$ and PF reactors, cell-shaped indentations were
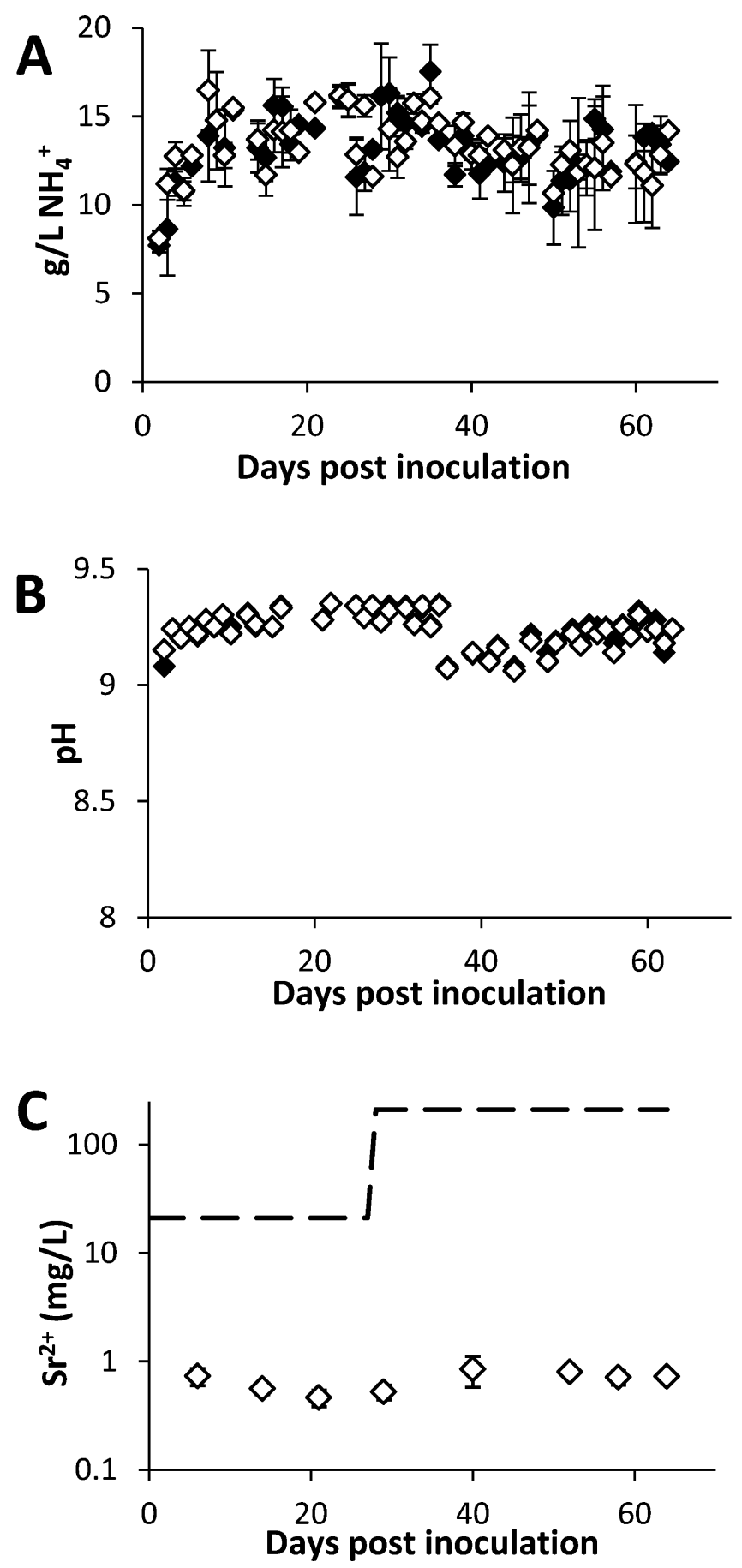

Figure 2. Effluent liquid analyses in pulsed flow reactors fed with $1 \mathrm{~g} /$ $\mathrm{L}$ Ca and sampled at the end of each batch phase. Effluent (A) total $\mathrm{NH}_{4}^{+}$and (B) pH were measured in Sr-free $(\diamond)$ and Sr-inclusive $(\diamond)$ reactors. (C) Effluent dissolved Sr; the dashed line indicates influent $\mathrm{Sr}$ concentration. Sr was increased to $210 \mathrm{mg} \mathrm{L}^{-1}$ on day 27 and is displayed on a logarithmic scale in part C. Urea and calcium are not shown, as they were not detected in effluent samples (quantification limits 10 and $5 \mathrm{mg} \mathrm{L}^{-1}$, respectively). Error bars are standard deviations of assays.

observed in crystals as well as cell-like shapes encased or coated with precipitates (Figure 3A,C).

Crystal size analysis of stereomicroscope images showed that average crystal size decreased from influent to effluent in reactors under both injection strategies (SI, Figures S4 and S5), 

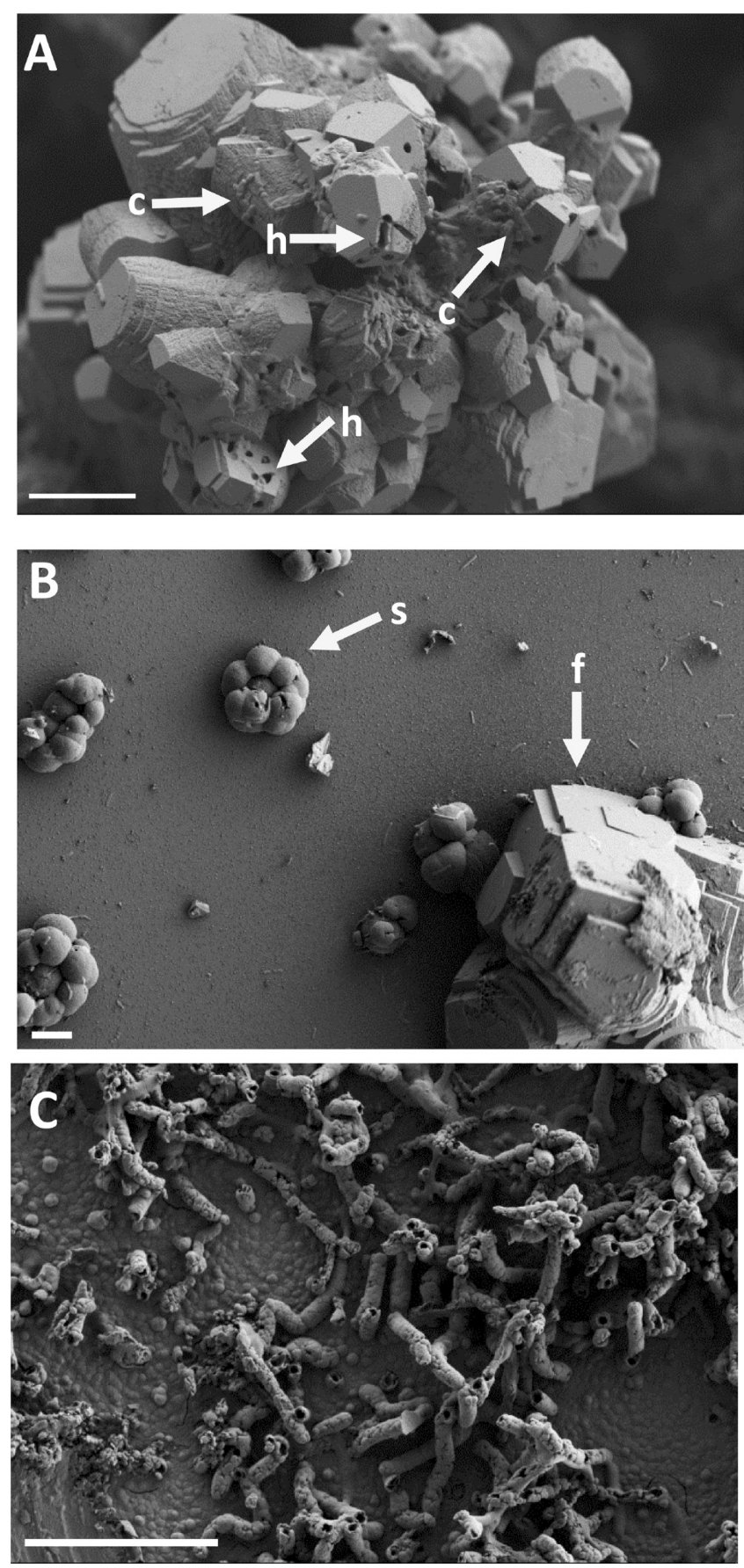

Figure 3. SEM images taken from the influent region of reactor glass coverslips upon destructive sampling. (A) PF reactor showing welldefined crystal faces, cells (c), and cell-shaped indentations (h). (B) CF Sr-inclusive reactor with well-defined crystal faces (f) and spherical precipitates (s). (C) Cell-like objects supposedly encased by precipitates. Scale bars are $10 \mu \mathrm{m}$.

although due to large standard deviations the change is not statistically significant (Figure 4). For CF conditions, the average crystal diameters were $60 \pm 15 \mu \mathrm{m}$ for the Sr-free reactor, and $32 \pm 8 \mu \mathrm{m}$ for the $\mathrm{Sr}$-inclusive reactor. Under PF conditions, the average crystal diameters were $40 \pm 20 \mu \mathrm{m}$ for the Sr-free reactor and $28 \pm 15 \mu \mathrm{m}$ for the Sr-inclusive reactor. The larger sizes of crystals in the absence of Sr were found to be statistically significant according to a two-sample $t$ test with a $P$-value of 0.05 . This may indicate that inhibition of crystal

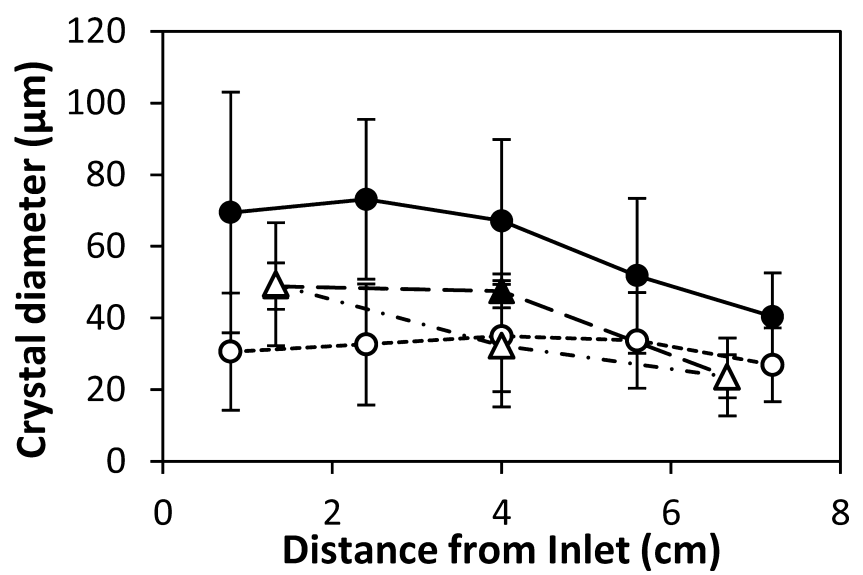

Figure 4. Crystal size of precipitates measured by stereomicroscope image analysis at the end of the experiment. CF conditions (circles) and PF conditions (triangles), Sr-free $(\boldsymbol{O}, \boldsymbol{\Delta})$ and $\operatorname{Sr}$-inclusive $(O, \Delta)$. Error bars are standard deviations of at least 20 crystal measurements.

growth occurred in the presence of $\mathrm{Sr}$, which is in agreement with results of previous research. ${ }^{19}$

Mass Balance and Rates of Precipitation. In the CF reactors, $72 \mathrm{mg}$ of $\mathrm{Ca}$ was recovered from the porous media of the $\mathrm{Sr}$-free reactor and $73 \mathrm{mg}$ from the Sr-inclusive reactor (Table 1). An overall precipitation efficiency of $61 \%$ was achieved in both reactors, suggesting that the presence of Sr did not severely affect $\mathrm{CaCO}_{3}$ precipitation under flow conditions, though it appears to have affected crystal size as discussed above. The calcium recovered from the acid digest of the complete reactor was $84-85 \mathrm{mg}$, less than predicted by effluent mass balance $(117 \mathrm{mg})$. The difference between the calculated and measured mass of $\mathrm{Ca}$ precipitates suggests that precipitation was occurring in the tubing outside of the reactor, or $\mathrm{CaCO}_{3}$ precipitates larger than the filter pore size of $0.2 \mu \mathrm{m}$ were exiting the reactor and were being trapped on the filters, resulting in reduced recovery of precipitated Ca. Regardless of whether suspended precipitates of $\mathrm{CaCO}_{3}$ were caught on the filters, the effluent results show that a high removal efficiency of Sr was achieved.

In the PF reactors, 213 and $185 \mathrm{mg}$ of Ca were recovered from the Sr-free and Sr-inclusive reactor respectively, which was greater than the $82 \mathrm{mg}$ total $\mathrm{Ca}$ that would have been available to precipitate in the reactors during the 30 periods of no flow. This indicates that ureolysis and $\mathrm{CaCO}_{3}$ precipitation occurred during the $30 \mathrm{~min}$ pulsed flow phase, during which two pore volumes of CMM were flushed through the reactors and during which the hydraulic residence time was roughly $10 \mathrm{~min}$ in the reactors.

Volumetric rates of calcite precipitation were calculated using effluent concentrations and normalized to reactor pore volume, with the pulsed reactors exhibiting slightly higher precipitation rates (Table 1). The rates shown for CF reactors in Table 1 are maximum rates at $11 \mathrm{~h}$ when complete ureolysis was occurring (Figure 1). The Ca precipitation rates of $(0.9-1.9) \times 10^{-3} \mathrm{~mol}$ $\mathrm{L}^{-1} \min ^{-1}\left(1.3-2.8 \mathrm{M} \mathrm{d}^{-1}\right)$ were much higher than previously reported ureolytically induced precipitation rates, including those determined by Tobler et al. $\left(0.18-1.6 \mathrm{mM} \mathrm{d}^{-1}\right){ }^{12}$ where higher $\mathrm{Ca}$ concentrations of 50-200 $\mathrm{mM}$ were used. Additionally, the rates calculated here are spatially averaged across the reactors and higher local rates may have occurred in proximity to ureolytically active cells. Rates of calcite precipitation in this study may be high due to the porous 
Table 1. Comparison of the Extent of Ca and Sr Immobilization and Precipitation Rates within the Reactors ${ }^{a}$

\begin{tabular}{|c|c|c|c|c|c|c|c|}
\hline & & \multirow[b]{2}{*}{ influent $\mathrm{Ca}(\mathrm{g} / \mathrm{L})$} & \multicolumn{2}{|c|}{$\begin{array}{l}\text { Ca precipitated in } \\
\text { porous media }\end{array}$} & \multirow[b]{2}{*}{ Ca precipitation rate $\left(\mathrm{mol} \mathrm{L}^{-1} \mathrm{~min}^{-1}\right)^{b}$} & \multicolumn{2}{|c|}{ Sr precipitated } \\
\hline & & & $\mathrm{mg}$ & $\%$ & & $\mathrm{mg}$ & $\%$ \\
\hline \multirow[t]{2}{*}{ continuous flow ${ }^{c}$} & Sr-free & 1 & 72 & 61 & $9.3 \times 10^{-4}$ & & \\
\hline & Sr-inclusive & 1 & 73 & 61 & $9.3 \times 10^{-4}$ & 8.4 & 56 \\
\hline \multirow[t]{2}{*}{ pulsed flow ${ }^{d}$} & Sr-free & 1 & 213 & 85 & $1.9 \times 10^{-3}$ & & \\
\hline & Sr-inclusive & 1 & 185 & 71 & $1.6 \times 10^{-3}$ & 20.1 & 59 \\
\hline pulsed flow-single inlet ${ }^{e}$ & Sr-free & 50 & 2400 & 36 & & & \\
\hline
\end{tabular}

${ }^{a}$ Precipitation rates in the PF reactors were estimated for the flow periods of calcium injection. ${ }^{b}$ Spatially averaged rates were calculated from effluent liquid data and flow rates. ${ }^{c}$ Duration of experiment was 11 h. ${ }^{d}$ Duration of experiment was 60 days. ${ }^{e}$ Duration of experiment was 51 days.

media reactor design, allowing greater surface area for nucleation. In this research, a nutrient-rich growth medium was used during both bacterial growth and mineralization periods, as compared to nutrient-minimal media used in other studies, such as artificial groundwater. This may contribute to the formation of more actively growing biofilms of $S$. pasteurii in this study and the ability of bacterial growth to overcome inactivation due to $\mathrm{CaCO}_{3}$ precipitation. It was not possible to accurately measure attached biomass in the reactors, particularly due to the potential encapsulation of cells within calcite precipitates. $^{26}$

In batch systems with a lower Ca concentration $(1.75 \mathrm{mM})$, Mitchell and Ferris ${ }^{22}$ reported that precipitation rates were similar in the presence and absence of $\mathrm{Sr}\left(2 \mathrm{mg} \mathrm{L}^{-1}\right)$. In this study, it is also apparent that the presence of 21 or $210 \mathrm{mg} \mathrm{L}^{-1}$ $\mathrm{Sr}$ does not significantly affect the calcite precipitation rate via ureolysis (Table 1). Concentrations of ${ }^{90} \mathrm{Sr}$ up to $231 \mathrm{mg} \mathrm{L}^{-1}$ have been reported in groundwater at contaminated DOE sites. $^{14}$

The high efficiency of precipitation in the PF strategy is also evident in an additional experiment performed with high $\mathrm{Ca}$ concentration ( $50 \mathrm{~g} \mathrm{Ca} \mathrm{L}^{-1}$ in CMM, no $\mathrm{Sr}$ ), in which $36 \%$ of $\mathrm{Ca}$ in the batch phase was precipitated after $26 \mathrm{CMM}$ pulses (Table 1). In this study, the extent of precipitation was limited by the maximum concentration of carbonate $\left(\mathrm{CO}_{3}{ }^{2-}\right)$ that could be generated by ureolysis $(333 \mathrm{mM})$ (eqs 1-3). This theoretically allowed for precipitation of only $333 \mathrm{mM}(13.3$ $\mathrm{g} \mathrm{L}^{-1}$ ) Ca, or only $26 \%$ of influent Ca, before all carbonate was consumed (eq 4). The greater than expected extent of precipitation in this reactor is also justified by $\mathrm{Ca}$ likely precipitating during the $30 \mathrm{~min}$ flow periods of media injection, as discussed above. In the $50 \mathrm{~g} \mathrm{~L}^{-1} \mathrm{Ca}$ experiment, effluent analysis indicated that $2.4 \mathrm{~g}$ of $\mathrm{Ca}$ precipitated in the reactors, or greater than 20 times the $\mathrm{Ca}$ that precipitated under $\mathrm{CF}$ conditions (Table 1), with a resulting pressure increase of only 0.3 psi. In contrast, the continuous flow reactors previously reported experienced complete reactor plugging, indicated by the inability to pump any fluid through the reactors. ${ }^{27}$

The PF strategy appears to effectively avoid plugging of the reactors, even though a higher mass of calcium carbonate was precipitated (Figure 5A, Table 1). This observation was supported by a reduced inlet pressure of the PF reactors compared to the CF reactors (data not shown). Applying a similar pulsed strategy in the field could also avoid permeability reduction issues during ${ }^{90} \mathrm{Sr}$ coprecipitation.

Coprecipitation of Strontium. Acid digestion verified the presence of $\mathrm{Sr}$ in the precipitates of the Sr-inclusive systems under both injection strategies. These results suggest that the experimental efficiency of Sr coprecipitation was $56 \%$ in the CF system and 59\% in the PF system, which included the CMM that flowed through the reactor during the injection period (Table 1). The molar ratio of $\mathrm{Sr}$ to $\mathrm{Ca}$ in the precipitates was similar in the CF and PF reactors and was relatively constant along the reactors with an average value of $0.05 \pm 0.004$ (Figure 5B).

Homogeneous partitioning coefficients $\left(D_{\mathrm{Sr}}\right)$ were calculated, which describe the extent of $\mathrm{Sr}$ removal from the aqueous phase into the mineral phase, relative to the precipitation of $\mathrm{Ca}$. In the PF reactors, the stagnation periods are similar to batch systems; thus, the following equation for a batch reaction, developed by Doerner and Hoskins, ${ }^{31}$ was used to calculate $D_{\mathrm{Sr}}$ using the initial and final liquid concentrations of $\mathrm{Sr}$ and $\mathrm{Ca}$ :

$$
D_{\mathrm{Sr}}=\frac{\ln \frac{[\mathrm{Sr}]_{\mathrm{f}}}{[\mathrm{Sr}]_{\mathrm{i}}}}{\ln \frac{[\mathrm{Ca}]_{\mathrm{f}}}{[\mathrm{Ca}]_{\mathrm{i}}}}
$$

In eq $5,[\mathrm{Sr}]$ and $[\mathrm{Ca}]$ are liquid concentrations, and the subscripts $f$ and $i$ denote final and initial concentrations during batch phase. Using a final $\mathrm{Ca}$ concentration of $5 \mathrm{mg} \mathrm{L}^{-1}$ (quantification limit of IC analysis) at the end of the batch phase in the Sr-inclusive reactor, the $D_{\mathrm{Sr}}$ calculated for the pulsed injection system was 0.74 during $21 \mathrm{mg} \mathrm{L}^{-1} \mathrm{Sr}$ addition and 1.1 during $210 \mathrm{mg} \mathrm{L}^{-1} \mathrm{Sr}$.

For the CF reactor, the $D_{\mathrm{Sr}}$ was calculated using the equation below: ${ }^{17}$

$$
D_{\mathrm{Sr}}=\frac{X_{\mathrm{Sr}}}{X_{\mathrm{Ca}}} \frac{[\mathrm{Ca}]}{[\mathrm{Sr}]}
$$

In eq $6, X$ is the solid phase molar concentration of $\mathrm{Sr}$ or $\mathrm{Ca}$ at a specific location in the reactor, while $[\mathrm{Ca}]$ and $[\mathrm{Sr}]$ are the liquid phase concentrations at the same location. While the solid phase ratio of $\mathrm{Sr}$ to $\mathrm{Ca}$ was measured along the reactor (Figure 5B), the liquid concentrations were only measured at the influent and effluent. Thus, $D_{\mathrm{Sr}}$ values were calculated by assuming both linear and exponentially decreasing concentration gradients between the reactor influent and effluent, which relate to either constant precipitation rate (linear) or $\mathrm{Ca}$ and $\mathrm{Sr}$ concentration dependent rate (exponential). $D_{\mathrm{Sr}}$ values were $0.80-1.0$ with a linear gradient and $0.38-0.77$ for the exponential gradient (Figure 5C), which are in the same range as for the pulsed reactor. The exponential gradient would indicate decreasing rates of $\mathrm{Ca}$ and $\mathrm{Sr}$ precipitation as liquid concentrations decrease toward the reactor effluent. In this case, the $D_{S r}$ is predicted to decrease over the reactor length, while a linear gradient results in a more constant $D_{\mathrm{Sr}}$ value with reactor length (Figure 5C). The extent to which $\mathrm{Sr}$ and other contaminants partition into calcite has previously been positively correlated with $\mathrm{CaCO}_{3}$ precipitation rates. ${ }^{19,21}$ Spatial sampling of the reactor is necessary to determine whether a 

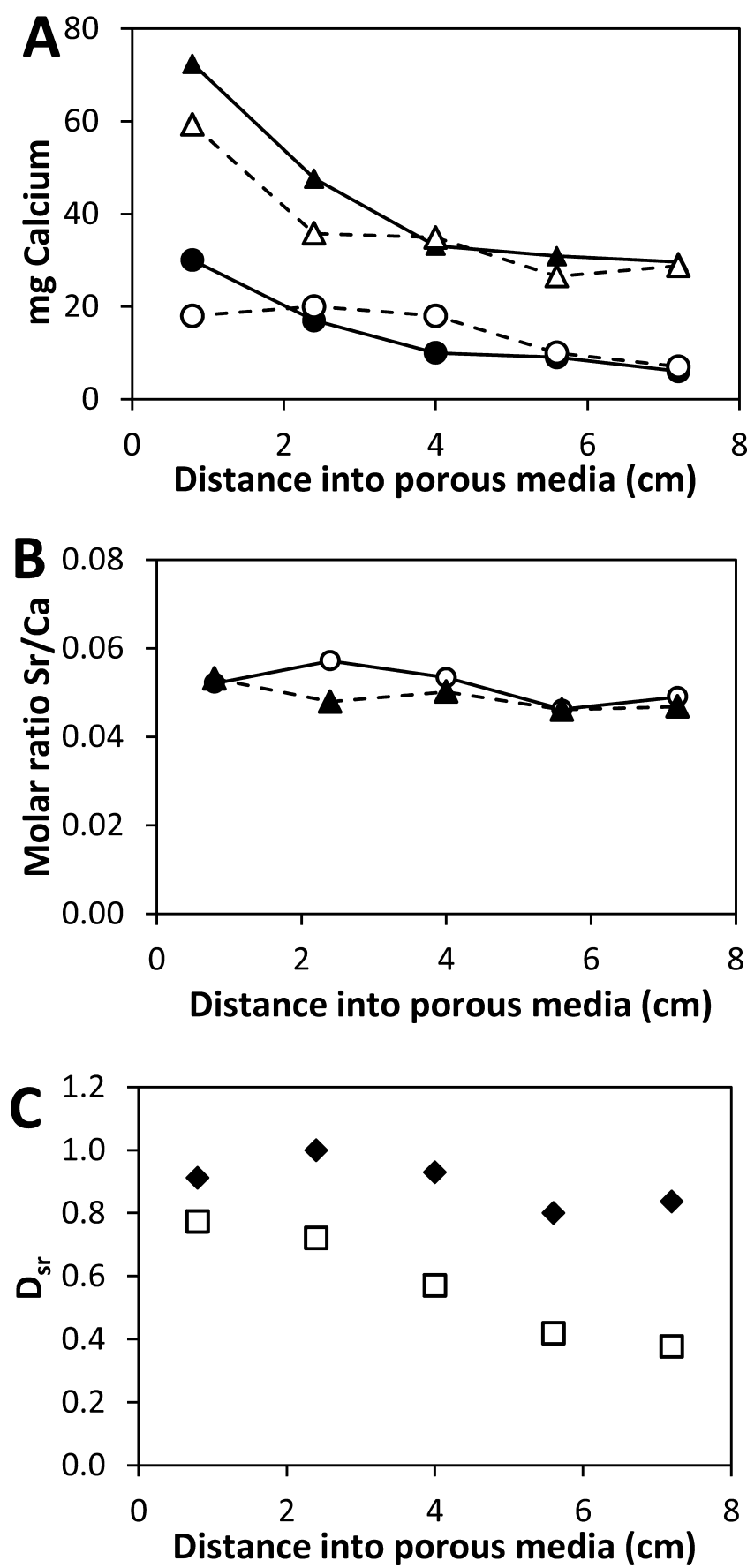

Figure 5. Spatial distribution of calcium and strontium in reactors. (A) Calcium mass in acid-digested precipitates under CF conditions (circles) and PF conditions (triangles), Sr-free $(\boldsymbol{\bullet}, \mathbf{\Delta})$ and Sr-inclusive $(\mathrm{O}, \Delta)$. (B) Ratio of $\mathrm{Sr}$ to $\mathrm{Ca}$ in acid-digested precipitates from Srinclusive reactors under $\mathrm{CF}(\mathrm{O})$ and $\mathrm{PF}(\boldsymbol{\Delta})$. (C) Homogeneous partitioning coefficient $\left(D_{\mathrm{Sr}}\right)$ in Sr-inclusive reactor under continuous flow assuming linear $(\diamond)$ and exponential $(\square)$ liquid concentration gradients. A weighted average of $125 \mathrm{mg} \mathrm{L}^{-1}$ of influent $\mathrm{Sr}$ was used for the $D_{\mathrm{Sr}}$ calculations.

linear or exponential gradient is present during continuous flow, but the current reactor design does not allow for such measurements.

These $D_{\mathrm{Sr}}$ values are slightly higher than those in previous studies of Sr coprecipitation in microbially induced calcite but are on the same order of magnitude. Mitchell and Ferris ${ }^{22}$ found $D_{\mathrm{Sr}}$ to be 0.46 at $20{ }^{\circ} \mathrm{C}$ during MICP with Sr, and Fujita et $\mathrm{al}^{21}$ determined a maximum $D_{\mathrm{Sr}}$ of 0.6 at the highest observed precipitation rate. As noted by Fujita et al., ${ }^{19} D_{\mathrm{Sr}}$ values of Sr coprecipitation into calcite under abiotic conditions are much lower than those observed for ureolytically driven calcite formation, which is also true for our study. In this study, the high $D_{\mathrm{Sr}}$ values compared to previous studies may be related to the high calcite precipitation rates. Regardless, there was no obvious difference between the Sr partitioning with the two injection strategies. These results show that the pulsed injection strategy was able to sequester at least the same fraction of dissolved $\mathrm{Sr}$ as the continuous flow injection.

Environmental Significance. The results presented here indicate the principal feasibility of ureolytic biofilm-mediated coprecipitation of $\mathrm{Sr}$ in calcium carbonate within porous media using two different injection strategies. In the pulsed flow (PF) systems, the mass and efficiency of $\mathrm{CaCO}_{3}$ precipitation were higher than in the continuous flow (CF) systems, and ureolytic activity was sustained over 60 days of reactor operation. The PF system resulted in similar $\mathrm{Sr}$ removal as the CF system, demonstrating that coprecipitation was effective under both flow scenarios. Thus, high flow rate pulses and intermittent batch periods can control distribution of precipitation while (i) still achieving efficient $\mathrm{Sr}$ coprecipitation, (ii) maintaining a viable ureolytic community over an extended period of time (60 days), and (iii) avoiding extensive plugging that would limit transport objectives.

Future studies will evaluate the optimization of injection strategies and feasibility in larger scale systems to ultimately develop an optimized approach for field-scale applications. The important influence of biofilm formation and mineral precipitation on fluid flow and mixing must be evaluated, and the two-dimensional reactors used in this research provide an ideal platform for such studies.

\section{ASSOCIATED CONTENT}

\section{Supporting Information}

Additional method details for modified Nessler assay, ion chromatography and SEM; reactor schematic; X-ray diffraction analysis of extracted precipitates, conducted in the Imaging and Chemical Analysis Laboratory (ICAL), Montana State University; and selected stereoscope images. This material is available free of charge via the Internet at http://pubs.acs.org/.

\section{AUTHOR INFORMATION}

\section{Corresponding Author}

*E-mail: robin_g@biofilm.montana.edu. Phone: (406) 9941840.

\section{Author Contributions}

\#E.G.L. and L.N.S. equally contributed to the experimental work, which provided the basis for this paper.

Notes

The authors declare no competing financial interest.

\section{ACKNOWLEDGMENTS}

This work was supported by the U.S. Department of Energy (DOE), Office of Science, Subsurface Biogeochemical Research (SBR) Program, contract no. DE-FG-02-09ER64758, and the DOE Zero Emissions Research Technology (ZERT) fund, award no. DE-FC26-04NT42262. The authors also acknowledge funding for the establishment and operation of the Environmental and Biofilm Mass Spectrometry Facility at Montana State University through the Defense University 
Research Instrumentation Program (DURIP, Contract Number: W911NF0510255) and the MSU Thermal Biology Institute from the NASA Exobiology Program (Project NAG5-8807).

\section{REFERENCES}

(1) Ferris, F. G.; Stehmeier, L. G.; Kantzas, A.; Mourits, F. M. Bacteriogenic mineral plugging. J. Can. Petrol. Technol. 1996, 35 (8), $56-61$.

(2) Whiffin, V. S.; van Paassen, L. A.; Harkes, M. P. Microbial carbonate precipitation as a soil improvement technique. Geomicrobiol. J. 2007, 24, 417-423.

(3) Mitchell, A.; Dideriksen, K.; Spangler, L.; Cunningham, A.; Gerlach, R. Microbially enhanced carbon capture and storage by mineral-trapping and solubility-trapping. Environ. Sci. Technol. 2010, 44 (13), 5270-5276.

(4) Stocks-Fischer, S.; Galinat, J. K.; Bang, S. S. Microbiological precipitation of $\mathrm{CaCO}_{3}$. Soil Biol. Biochem. 1999, 31 (11), 1563-1571.

(5) Fujita, Y.; Ferris, E. G.; Lawson, R. D.; Colwell, F. S.; Smith, R. W. Calcium carbonate precipitation by ureolytic subsurface bacteria. Geomicrobiol. J. 2000, 17 (4), 305-318.

(6) Ferris, F. G.; Phoenix, V.; Fujita, Y.; Smith, R. W. Kinetics of calcite precipitation induced by ureolytic bacteria at 10 to 20 degrees $\mathrm{C}$ in artificial groundwater. Geochim. Cosmochim. Acta 2004, 68 (8), 1701-1710.

(7) Hammes, F.; Verstraete, W. Key roles of $\mathrm{pH}$ and calcium metabolism in microbial carbonate precipitation. Rev. Environ. Sci. Biotechnol. 2002, 1 (1), 3-7.

(8) Ferris, F. G.; Fyfe, W. S.; Beveridge, T. J. Bacteria as nucleation sites for authigenic minerals in a metal-contaminated lake sediment. Chem. Geol. 1987, 63 (3-4), 225-232.

(9) Fujita, Y.; Taylor, J. L.; Gresham, T. L. T.; Delwiche, M. E.; Colwell, F. S.; McLing, T. L.; Petzke, L. M.; Smith, R. W. Stimulation of microbial urea hydrolysis in groundwater to enhance calcite precipitation. Environ. Sci. Technol. 2008, 42 (8), 3025-3032.

(10) Mitchell, A. C.; Ferris, F. G. The influence of Bacillus pasteurii on the nucleation and growth of calcium carbonate. Geomicrobiol. J. 2006, 23 (3-4), 213-226.

(11) Okwadha, G. D. O.; Li, J. Optimum conditions for microbial carbonate precipitation. Chemosphere 2010, 81 (9), 1143-1148.

(12) Tobler, D. J.; Cuthbert, M. O.; Greswell, R. B.; Riley, M. S.; Renshaw, J. C.; Handley-Sidhu, S.; Phoenix, V. R. Comparison of rates of ureolysis between Sporosarcina pasteurii and an indigenous groundwater community under conditions required to precipitate large volumes of calcite. Geochim. Cosmochim. Acta 2011, 75 (11), 3290-3301.

(13) Mobley, H. L. T.; Island, M. D.; Hausinger, R. P. Molecularbiology of microbial ureases. Microbiol. Rev. 1995, 59 (3), 451-480.

(14) Riley, R. G.; Zachara, J. M. Chemical Contaminants on DOE Lands and Selection of Contaminant Mixtures for Subsurface Science Research; Office of Energy Research, U.S. Department of Energy: Washington, DC, 1992.

(15) NRC. Research Needs in Subsurface Sciences-U.S. Department of Energy's Environmental Management Science Program, National Research Council; National Academy Press: Washington, DC, 2000; pp 15-46.

(16) USEPA. EPA Facts about Strontium-90; USEPA: Washington, DC, 2002.

(17) Curti, E. Coprecipitation of radionuclides with calcite: Estimation of partition coefficients based on a review of laboratory investigations and geochemical data. Appl. Geochem. 1999, 14 (4), 433-445.

(18) Brookshaw, D.; Pattrick, R.; Lloyd, J.; Vaughan, D. Microbial effects on mineral-radionuclide interactions and radionuclide solidphase capture processes. Mineral. Mag. 2012, 76 (3), 777-806.

(19) Mitchell, A. C.; Ferris, F. G. Effect of strontium contaminants upon the size and solubility of calcite crystals precipitated by the bacterial hydrolysis of urea. Environ. Sci. Technol. 2006, 40 (3), 10081014.
(20) Warren, L. A.; Maurice, P. A.; Parmar, N.; Ferris, F. G. Microbially mediated calcium carbonate precipitation: Implications for interpreting calcite precipitation and for solid-phase capture of inorganic contaminants. Geomicrobiol. J. 2001, 18 (1), 93-115.

(21) Fujita, Y.; Redden, G.; Ingram, J.; Cortez, M.; Ferris, F.; Smith, R. Strontium incorporation into calcite generated by bacterial ureolysis. Geochim. Cosmochim. Acta 2004, 68 (15), 3261-3270.

(22) Mitchell, A. C.; Ferris, F. G. The coprecipitation of Sr into calcite precipitates induced by bacterial ureolysis in artificial groundwater: Temperature and kinetic dependence. Geochim. Cosmochim. Acta 2005, 69 (17), 4199-4210.

(23) Research Needs in Subsurface Sciences-U.S. Department of Energy's Environmental Management Science Program; National Academy Press: Washington, DC, 2000.

(24) Fujita, Y.; Taylor, J. L.; Wendt, L. M.; Reed, D. W.; Smith, R. W. Evaluating the potential of native ureolytic microbes to remediate a (90)Sr contaminated environment. Environ. Sci. Technol. 2010, 44 (19), 7652-7658.

(25) Ebigbo, A.; Phillips, A.; Gerlach, R.; Helmig, R.; Cunningham, A. B.; Class, H.; Spangler, L. H. Darcy-scale modeling of microbially induced carbonate mineral precipitation in sand columns. Water Resour. Res. 2012, 48.

(26) Cuthbert, M. O.; Riley, M. S.; Handley-Sidhu, S.; Renshaw, J. C.; Tobler, D. J.; Phoenix, V. R.; Mackay, R. Controls on the rate of ureolysis and the morphology of carbonate precipitated by S. pasteurii biofilms and limits due to bacterial encapsulation. Ecol. Eng. 2012, 41, $32-40$.

(27) Schultz, L.; Pitts, B.; Mitchell, A. C.; Cunningham, A. B.; Gerlach, R. Imaging biologically induced mineralization in fully hydrated flow systems. Microsc. Today 2011, 19 (5), 12-15.

(28) Clark, S.; Francis, P.; Conlan, X.; Barnett, N. Determination of urea using high-performance liquid chromatography with fluorescence detection after automated derivatisation with xanthydrol. J. Chromatogr. A 2007, 1161 (1-2), 207-213.

(29) Herigstad, B.; Hamilton, M.; Heersink, J. How to optimize the drop plate method for enumerating bacteria. J. Microbiol. Methods 2001, 44 (2), 121-129.

(30) Tobler, D.; Maclachlan, E.; Phoenix, V. Microbially mediated plugging of porous media and the impact of differing injection strategies. Ecol. Eng. 2012, 42, 270-278.

(31) Doerner, H.; Hoskins, W. Co-precipitation of radium and barium sulfates. J. Am. Chem. Soc. 1925, 47, 662-675. 